See Editorial page 2340.

\section{Commentary: Thoracic surgery residency: Not a spectator sport}

\author{
John Calhoon, MD, and Christian Jacobsen, BS
}

The great author C. S. Lewis once said, "No one can teach riding so well as a horse." While this statement might crack a smile, it reflects Dr Stephens's thoughts on learning through practice as a resident. Specifically, deliberate practice remains theoretical until it is actually practiced. We can talk about riding horses all we want, but until a potential rider mounts the saddle, feels the horse quiver beneath their weight, and begins to ride, they will not excel. Similarly, residents must find a personalized way to deliberately and intentionally practice cardiac surgery.

Dr Stephens's thoughts on learning reflect a common misconception held within our educational system. ${ }^{1}$ Modern educational curriculums often project a one-size-fits-all or "my way or the highway" approach to teaching that doesn't necessarily work for all students. Individual students are motivated differently, and they learn in distinct ways.

With that in mind, Dr Stephens's paper encourages attendings to foster a spirit of innovation and autonomy among the residents. They are soon expected to be autonomous surgeons, so why not practice autonomy as learners? As she hints, perhaps students rely too heavily on their program and at times fail to own their education. Medical students are prone to developing an external locus of control, as they tie their future success to the prestige of the school or residency that accepts them. Yes, to some extent, how well a resident is trained depends on the program a resident selects as well as their inherent gifts and intellect. However, we have all seen undergraduates attend a fantastic college and come away with little to show for it whereas other students

\footnotetext{
From the Department of CT Surgery, UTHSCSA, San Antonio, Tex.

Disclosures: Authors have nothing to disclose with regard to commercial support.

Received for publication Dec 16, 2019; revisions received Dec 16, 2019; accepted for publication Dec 16, 2019; available ahead of print Jan 29, 2020.

Address for reprints: John Calhoon, MD, Department of CT Surgery, UTHSCSA, San Antonio, TX 78229 (E-mail: calhoon@uthscsa.edu).

J Thorac Cardiovasc Surg 2020;159:2345-6

$0022-5223 / \$ 36.00$

Copyright (c) 2020 by The American Association for Thoracic Surgery

https://doi.org/10.1016/j.jtcvs.2019.12.047
}

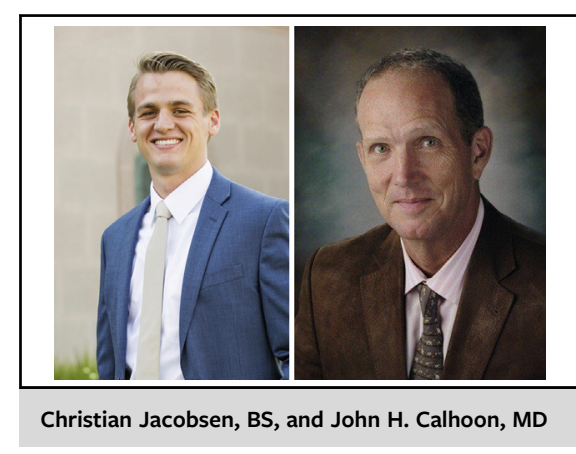

CENTRAL MESSAGE

Thoracic surgical education depends on the program embracing education and the learner doing their part. Together, innovative excellent surgeons are created.

might attend less-prestigious colleges and make the most of their time. In short, training is to a largely dependent on one's personal investment.

Toward the end of her account, Dr Stephens mentions some of the barriers that keep residents from learning. She addresses the stumbling block of shame. This reminds me of the constant need to be humble in the field of cardiothoracic surgery. Confucius said, "A man who asks is a fool for five minutes. A man who never asks is a fool for life." It is important to remain teachable, humble, and willing to learn. Cardiac surgeons should be mindful to foster an environment of kindness and patience for learners at every level. A culture of shame is more likely to germinate ignorance and contempt. An environment of respect and patience breeds education and innovation.

There is always room to improve the manner and culture surrounding resident education. Dr Stephens highlights the importance resident ownership has to learning and the need for programs to embrace different learning styles while striving to create approachability in our operating rooms. 
Her article reminds us that life is a series of challenges towards lifelong improvement.

\section{Reference}

1. Stephens E. It's a long way to the other side of the table. J Thorac Cardiovasc Surg. 2020;159:2340-3. 